\title{
Government Size And The International Mobility Of Capital
}

Atul A. Dar, Saint Mary's University, Canada

Sal AmirKhalkhali, Saint Mary’s University, Canada

\begin{abstract}
This paper examines how government size impacts on the degree of capital mobility among 23 industrial countries by estimating saving-investment correlations using an error-correction model, with random coefficients, from data for the 1970-2006 period. The error-correction approach allows us to integrate both short-run and long-run behaviour within a single model. This is important if the model is to be given a capital mobility interpretation, because the savinginvestment correlation relevant for assessing capital mobility is a long run one. Further, a model with random coefficients is a more general way of incorporating unmeasured differences between countries. Our sample is classified into five groups according to government size, which is measured by the ratio of government expenditures to GDP, and the model is estimated for each group separately using the random coefficients estimator. Our results find some support for the view that countries with larger governments also have lower capital mobility.
\end{abstract}

Keywords: saving, investment, government size, and capital mobility

\section{INTRODUCTION}

here has been considerable interest in explaining the saving- investment relationship and its implications for capital mobility. In large part, this has been the result of a set of papers by Feldstein and Horioka (1980) and Feldstein (1983) examining the relationship between the saving and investment rates of a sample of industrialized countries. Their results pointed to the existence of a strong relationship between investment and saving rates, with a saving retention coefficient in a regression of investment rates on saving rates being close to unity. They interpreted that finding as implying that the assumption of perfect capital mobility is invalid. The finding has far reaching implications. For instance, with low international capital mobility, a country's growth prospects would be constrained by its saving effort. If the saving effort is weak relative to investment opportunities, realized investment rates could fall short of their potential, and thus impact adversely on growth. It also implies that fiscal deficits lead to neoclassical crowding out of investment, so that both the Keynesian view, as well as the Ricardian Equivalence proposition do not hold.

A large number of studies have attempted to offer alternative explanations for the strong correlation between saving and investment. Earlier studies attributed the observed saving-investment correlations to a number of other casual factors - from the response of the current account to investment shocks [(Sachs 1981, 1983)], the effects of country size [Harberger (1980), and Murphy (1985)], to the response of government to current account imbalances [Tobin (1983), Obstfeld (1986), Summers (1998)], and econometric weaknesses of the Feldstein and Horioka methodology [(Dooley (1985), and Dooley, Frankel and Mathieson (1987)]. Feldstein and Bacchetta (1991) re-examined the issue in light of the criticism and concluded that the strong positive saving-investment correlation is quite robust and reflects low capital mobility. Some other empirical studies also appear to suggest that the Feldstein and Horioka (FH) study is, in many ways, more robust than its critiques [see for instance, Frankel (1991), AmirKhalkhali and Dar (1993)].

Recent explanations for the observed saving and investment correlation have shifted their focus and sought to explain the strong correlation within the context of theoretical open-economy macro models. For instance, a persistent, positive correlation between saving and investment might alternatively reflect an intertemporal budget 
constraint. Specifically, within the context of the generic intertemporal open-economy macro model in which capital mobility is perfect, an intertemporal budget constraint implies that the ratio of current account to GDP must be constant in the long run, which would, via the accounting identity, imply that the relationship between the saving rate and investment rate is one-to-one. In other words, this one-to-one relationship could reflect the budget constraint and not zero long run capital mobility. Another implication of such models is the distinction between short-run dynamics and the long-run equilibrium. From an empirical perspective this can be addressed by looking at time series econometric models that employ the error-correction mechanism [see, for instance, Jansen $(1996,1998)]$. According to Jansen, while attributing high positive correlations between saving and investment ratios to limited capital mobility might well have some validity, such correlations are also consistent with intertemporal budget constraints and high capital mobility.

In this study, we examine how government policy influences the saving-investment relationship and what implications follow for capital mobility. Specifically, we ask the question: are countries with relatively bigger governments are also characterized by lower capital mobility? This could be the case if such governments more interventionist, and segment their capital markets from international capital markets beyond levels that would otherwise occur. For instance, legal restrictions on institutional investors such as insurance companies and pension funds could limit the amount they can invest abroad; alternatively, the risk of capital controls, and changes in government regulations, tax rules, and government procurement rules in ways that are especially disadvantageous to foreign investors, could inhibit flows of direct investment [Feldstein (1994)]. Note that it is not so much that these impediments actually have to be in place to reduce capital mobility; rather it is the perceived risk that these might occur, which could deter investors from shifting capital abroad. It seems reasonable to assume that more interventionist governments are more likely to have a policy framework in place that is relatively more detrimental to the free flow of capital. Alternatively the likelihood of that happening is perceived by investors to be greater in countries with such governments. In either case, the effect would be to reduce the degree of capital mobility.

The empirical model employed in our study is an error-correction model with random coefficients, which we apply to data on twenty three OECD countries over the 1970-2006 period. The error-correction mechanism is employed in order to distinguish between short-run and long-run behaviour. This is important if the model is to be given a capital mobility interpretation because, as noted by Feldstein (1994), the saving-investment correlation relevant for assessing capital mobility is a long run one. The error-correction approach allows us to integrate both short-run and long-run behaviour within a single model. Further, the evidence in Jansen (1998) clearly points to the need for accommodating significant inter-country differences. Jansen attempts to deal with this issue by using a fixed effects approach. However, a model with random coefficients is a more general way of incorporating unmeasured differences between countries, differences that neither a random effects or fixed effects approach could not adequately capture. We first investigate the aggregate saving-investment relationship using random coefficients for all 23 countries. Following that, these countries are classified into five groups on the basis of the relative size of government, measured as the ratio of government expenditure to GDP, and this relationship is estimated for each of these groups, to examine how government size impacts on the long run saving-investment correlation, and the implications for the degree of capital mobility.

\section{THE MODEL, ESTIMATION STRATEGY AND EMPIRICAL RESULTS}

The sample used in this study consists of annual data for twenty three countries: Australia, Austria, Belgium, Canada, Denmark, Finland, France, Germany, Greece, Iceland, Ireland, Italy, Japan, Luxembourg, Netherlands, New Zealand, Norway, Portugal, Spain, Sweden, Switzerland, the United Kingdom (UK), and the United States (USA), covering the 1970-2006 period. The data were obtained from various issues of Economic Outlook published by Organization for Economic Cooperation and Development (OECD) and International Financial Statistics published by International Monetary Fund (IMF). Table 1 below presents averages of the relative size of government measured as the ratio of government expenditure to GDP, and average ratios of saving (S), and investment (I) over the study period for each of the countries in the sample. These countries have been classified into five groups, depending upon the average size of government over the 1970-2006 interval. Group I countries (Switzerland, Japan, USA, Australia, and Ireland) display the smallest size of government spending, lying in the 34-39 percent range. Government spending is largest in Group V countries (Denmark and Sweden), varying in the 57-63 percent range. Group III countries (Canada, Germany, Netherlands, and Greece) constitute the median group in which government 
spending varies in the 46-49 percent range. Group IV countries (Norway, Belgium, Italy, France, Austria, and Finland) are the group with a medium-to-large government spending, lying in the 50-54 percent range, while Group II countries (Spain, UK, Portugal, New Zealand, Luxembourg, and Iceland) are those with a small-to-medium government sector, varying in the $42-44$ percent range.

Table 1

Average Saving and Investment Ratios, and Government Size: 1970-2006

\begin{tabular}{|l|c|c|c|}
\hline \multicolumn{1}{|c|}{ Countries } & S & I & Government Size \\
\hline Switzerland & 24.8 & 27.3 & 34.0 \\
\hline Japan & 29.6 & 31.1 & 35.2 \\
\hline US & 18.9 & 17.0 & 36.3 \\
\hline Australia & 24.9 & 23.1 & 37.3 \\
\hline Ireland & 23.2 & 25.6 & 39.0 \\
\hline Spain & 24.3 & 22.8 & 41.7 \\
\hline U.K. & 17.9 & 16.8 & 42.5 \\
\hline Portugal & 27.0 & 15.9 & 43.3 \\
\hline New Zealand & 23.6 & 23.0 & 43.6 \\
\hline Luxembourg & 23.7 & 33.6 & 43.6 \\
\hline Iceland & 22.9 & 21.6 & 43.7 \\
\hline Canada & 21.3 & 23.1 & 45.9 \\
\hline Germany & 21.9 & 23.8 & 47.1 \\
\hline Netherlands & 21.3 & 25.6 & 48.9 \\
\hline Greece & 24.0 & 15.7 & 49.3 \\
\hline Norway & 26.0 & 31.1 & 50.3 \\
\hline Belgium & 20.4 & 22.4 & 51.0 \\
\hline Italy & 22.4 & 22.8 & 51.9 \\
\hline France & 21.5 & 22.1 & 52.3 \\
\hline Austria & 24.0 & 25.7 & 52.8 \\
\hline Finland & 23.7 & 26.6 & 53.6 \\
\hline Denmark & 20.5 & 22.6 & 56.8 \\
\hline Sweden & 18.9 & 22.0 & 62.9 \\
\hline
\end{tabular}

In our study, the model of the saving-investment relationship is an extension of the Jansen (1996) errorcorrection model. Our starting point is to re-state the Jansen model as follows:

$\Delta \mathrm{I}_{\mathrm{it}}=\mathrm{a}+\beta \Delta \mathrm{S}_{\mathrm{it}}+\gamma \mathrm{CA}_{\mathrm{it}-1}+\delta \mathrm{S}_{\mathrm{it}-1}+\mathrm{W}_{\mathrm{it}}{ }^{\prime} \theta$

where I, S and CA are ratios of investment (gross fixed capital formation), saving (basic saving calculated as GDP minus private and public consumption expenditure) and current account ( $\mathrm{S}-\mathrm{I}$ ) to GDP, respectively. $\Delta$ stands for the first difference, and the subscripts $\mathrm{i}(\mathrm{i}=1,2, \ldots, \mathrm{N})$ and $\mathrm{t}(\mathrm{t}=1,2, \ldots, \mathrm{T})$ index the countries and time periods in the sample respectively. W represents a set of excluded variables that in conjunction with the included explanatory variables, are sufficient to determine the dependent variable. $\mathrm{a}, \beta, \gamma, \delta$, and $\theta$ are the regression parameters.

In the model given by (1), the regression parameters, as well as the vector of excluded variables W, are not unique since they are sensitive to the parameterization adopted. To make the coefficients unique, we assume that W and the explanatory variables are related as follows:

$\mathrm{W}_{\mathrm{it}}=\eta_{1 \mathrm{i}}+\eta_{2 \mathrm{i}} \Delta \mathrm{S}_{\mathrm{it}}+\eta_{3 \mathrm{i}} \mathrm{CA} \mathrm{A}_{\mathrm{it}-1}+\eta_{4 \mathrm{i}} \mathrm{S}_{\mathrm{it}-1}+\mathrm{v}_{\mathrm{it}}$

Substituting (2) into equation (1) gives

$\Delta \mathrm{I}_{\mathrm{it}}=\mathrm{a}_{\mathrm{i}}+\beta_{\mathrm{i}} \Delta \mathrm{S}_{\mathrm{it}}+\gamma_{\mathrm{i}} \mathrm{CA}_{\mathrm{it}-1}+\delta_{\mathrm{i}} \mathrm{S}_{\mathrm{it}-1}+\mathrm{u}_{\mathrm{it}}$

where $a_{i}=a+\eta_{1 i}^{\prime} \theta, \beta_{i}=\beta+\eta_{2 i}^{\prime} \theta, \gamma_{i}=\gamma+\eta_{3 i}^{\prime} \theta, \delta_{i}=\delta+\eta_{4 i}^{\prime} \theta$, and $u_{i t}=v_{i t}{ }^{\prime} \theta$. 
This is a varying-coefficients specification that may be seen as a refinement of the stochastic law relating investment rates to its main determinants [see Pratt and Schlaifer $(1984,1988)]$. The $\beta_{\mathrm{i}}$ measure the short-run correlation between saving and investment. The other parameters $\mathrm{a}_{\mathrm{i}}, \gamma_{\mathrm{i}}$ and $\delta_{\mathrm{i}}$ have important long run implications for the saving-investment relationship. In particular, $\gamma_{\mathrm{i}}$ is the cointegrating parameter, and rejecting the hypothesis that $\gamma_{\mathrm{i}}=$ $\mathrm{O}$, would imply a long-run relationship between saving and investment. This long-run relationship can be shown to be:

$\mathrm{I}_{\mathrm{i}}=\left(\mathrm{a}_{\mathrm{i}} / \gamma_{\mathrm{i}}\right)+\left[1+\left(\delta_{\mathrm{i}} / \gamma_{\mathrm{i}}\right] \mathrm{S}_{\mathrm{i}}+\mathrm{u}_{\mathrm{i}}^{*}\right.$

where $\mathrm{u}_{\mathrm{i}}{ }^{*}=\mathrm{u}_{\mathrm{i}} / \gamma_{\mathrm{i}}$. A failure to reject $\delta_{\mathrm{i}}=0$ could be interpreted as implying that the intertemporal budget constraint is obeyed and the current account fluctuates around a constant $-\left(\mathrm{a}_{\mathrm{i}} / \gamma_{\mathrm{i}}\right)$ in the long run. If additionally $\mathrm{a}_{\mathrm{i}}=0$, then the current account would fluctuate around zero. In either case, the relationship between I and S would be one-for-one, which in the FH tradition is indicative of no capital mobility, although it could also reflect the intertemporal budget constraint. On the other hand, rejecting the hypothesis $\delta_{\mathrm{i}}=0$ would imply that the current account is non-stationary, and this would allow us to draw firmer inferences about the degree of capital mobility, since in this case, the intertemporal budget constraint does not hold. In general, in this case capital mobility can be expected to be relatively higher, the degree depending upon the size of the long run saving retention coefficient $\left[1+\left(\delta_{\mathrm{i}} / \gamma_{\mathrm{i}}\right)\right]$ which would be bounded from above by unity, since we expect $\delta_{\mathrm{i}}$ to be non-positive.

In studying the saving-investment relationship for this sample of countries, we estimated the errorcorrection model (3). In the first instance, the model is estimated for the entire sample by pooling over all 23 countries over the 1970-2006 interval using random coefficients estimation. The parameters are then permitted to vary across the five groups, classified according to government size, and estimated for each group, again using random coefficients. For a discussion of the details of the random coefficients techniques employed in this study see Swamy (1970), Swamy and Mehta (1975), and Swamy and Tavlas $(1995,2002)$. We discuss the results for each of these cases in turn.

Table 2 reports the results for the pooled sample. At the 5 percent (or less) significance level, the GLS estimates imply a statistically significant short run as well as long run relationships between saving and investment. However, the failure to reject $a=\delta=0$ suggests that the current account is stationary and fluctuates around zero in the long run. The one-for-one relationship between I and S could indicate low capital mobility, or that the intertemporal budget constraint is valid. Accordingly, no clear conclusion about the degree of capital mobility can be drawn. Note though that the validity of the random coefficients model is supported by a highly significant Swamy's g-statistic that follows a $\chi^{2}$ distribution under the null hypothesis of fixed coefficients [see Swamy (1970) for more details].

Table 2

Pooled Regression Results: Random Coefficients GLS

Model : $\Delta \mathbf{I}_{\mathrm{it}}=\boldsymbol{a}_{\mathrm{i}}+\boldsymbol{\beta}_{\mathrm{i}} \Delta \mathbf{S}_{\mathrm{it}}+\gamma_{\mathrm{i}} \mathbf{C A}_{\mathrm{it}-1}+\boldsymbol{\delta}_{\mathrm{i}} \mathbf{S}_{\mathrm{it}-1}+\mathbf{u}_{\mathrm{it}}$

\begin{tabular}{|c|c|c|c|c|}
\hline Countries & $\mathbf{a}$ & $\boldsymbol{\beta}$ & $\boldsymbol{\gamma}$ & $\boldsymbol{\delta}$ \\
\hline All & 0.934 & $0.528^{*}$ & $0.222^{*}$ & -0.037 \\
& $(1.068)$ & $(0.097)$ & $(0.047)$ & $(0.045)$ \\
\hline G-Statistic $=295.9^{*}$ & \multicolumn{4}{|r}{} \\
\hline
\end{tabular}

* indicates statistical significance at the $5 \%$ level or less

Figures in brackets are corresponding standard errors.

To make generalizations (if any) about the role of government policy, and to assess the sensitivity of our results to he relative size of government, we also classify countries into the five groups as indicated earlier, and estimate the random coefficients error-correction model separately for each group. The group-specific results are reported in Table 3. 
Table 3

Group-Wise Regression Results: Random Coefficients GLS

\begin{tabular}{|c|c|c|c|c|}
\hline Groups & a & $\beta$ & $\gamma$ & $\delta$ \\
\hline Switzerland, Japan, USA, Austria, Ireland & $\begin{array}{l}1.268^{*} \\
(0.412)\end{array}$ & $\begin{array}{l}0.473^{*} \\
(0.072)\end{array}$ & $\begin{array}{l}0.101 * \\
(0.019)\end{array}$ & $\begin{array}{l}-0.061 * \\
(0.016)\end{array}$ \\
\hline $\begin{array}{l}\text { Group II } \\
\text { Spain, UK, Portugal, New Zealand, } \\
\text { Luxembourg, Iceland }\end{array}$ & $\begin{array}{l}2.746^{*} \\
(0.446)\end{array}$ & $\begin{array}{c}0.092 \\
(0.067)\end{array}$ & $\begin{array}{l}0.127 * \\
(0.018)\end{array}$ & $\begin{array}{l}-0.118 * \\
(0.018)\end{array}$ \\
\hline $\begin{array}{c}\text { Group III } \\
\text { Canada, Germany, } \\
\text { Netherlands, Greece }\end{array}$ & $\begin{array}{l}1.605^{*} \\
(0.447)\end{array}$ & $\begin{array}{l}0.473 * \\
(0.064)\end{array}$ & $\begin{array}{l}0.098 * \\
(0.019)\end{array}$ & $\begin{array}{l}-0.076^{*} \\
(0.019)\end{array}$ \\
\hline $\begin{array}{c}\text { Group IV } \\
\text { Norway, Belgium, Italy, } \\
\text { France, Austria, Finland }\end{array}$ & $\begin{array}{l}1.459 * \\
(0.493)\end{array}$ & $\begin{array}{l}0.279 * \\
(0.073)\end{array}$ & $\begin{array}{l}0.155^{*} \\
(0.021)\end{array}$ & $\begin{array}{c}-0.077 * \\
(0.019)\end{array}$ \\
\hline$\frac{\text { Group V }}{\text { Denmark and Sweden }}$ & $\begin{array}{c}0.581 \\
(0.510)\end{array}$ & $\begin{array}{l}0.553 * \\
(0.094)\end{array}$ & $\begin{array}{l}0.138^{*} \\
(0.025)\end{array}$ & $\begin{array}{l}-0.046^{*} \\
(0.021)\end{array}$ \\
\hline
\end{tabular}

* indicates statistical significance at the 5\% level or less.

Figures in brackets are corresponding standard errors

Looking first at the Swamy's g-statistic, we can see that the validity of the random coefficients model is supported by the statistically significant value of calculated g-statistic for distinguishing the five groups. The estimates of the short-run correlations are positive and statistically significant for all groups but Group II. As far as the magnitude of impacts is concerned, the significant estimates of short-run correlation between saving and investment vary from a low of 0.28 for Group IV to a high of 0.55 for Group V. With regard to the cointegrating parameters, all estimates are positive and statistically significant for all five groups, thereby supporting the existence of a long-run relation between saving and investment for each group. The estimate of $\delta$ is negative and also statistically significant for all countries. This would imply that the current account is non-stationary, which supports the existence of capital mobility for all groups. In general, the degree of capital mobility varies across these groups. A sense of how much can be obtained from the estimates of the long-run saving retention coefficient in equation (4). This works out to $0.40,0.08,0.22,0.50,0.67$ for groups I through $\mathrm{V}$, respectively. It is evident from this that the degree of capital mobility is generally lower in countries with higher government spending, as can be seen by comparing the estimates for groups II, III, IV, V. The estimate for Group I (countries with the smallest government size) seems to be counter to this. One reason for this could be that the government size impacts are contaminated by country size effects. One would expect higher saving retention coefficients for larger countries [Feldstein (1994)]. This could mean that the influence of Japan and the US pushes up the estimate of this coefficient for Group I, especially since the other countries in this group are the smallest in the sample. Overall, these results provide some support for the view that capital mobility is lower in countries with larger governments.

\section{CONCLUSION}

In this paper, we examined the saving-investment relationship among 23 OECD countries over the 19702006 interval. Our aim was to determine whether the size of the government sector influences that relationship and what implications follow for capital mobility. The specific question was: are countries with greater government size also characterized by lower capital mobility? We applied an error-correction model with random coefficients to look at this question. The error-correction mechanism was employed in order to distinguish between short run and long run behaviour. This is important if the model is to be given a capital mobility interpretation because, as noted by Feldstein (1994), the saving-investment correlation relevant for assessing capital mobility is a long run one. The error correction approach allowed us to integrate both within a single model. Further, we extended the standard error correction model by allowing it to display random coefficients, which is a more general way of incorporating unmeasured differences between countries, differences that neither a random effects or fixed effects approach could not adequately capture. We first investigated the aggregate and country-specific saving-investment-current account 
relationship for all 23 countries. Following that, these countries were classified into five groups on the basis of the relative size of government, measured as the ratio of government expenditure to GDP, and this relationship was estimated for each of these groups, to examine how government size impacts on the long run saving-investment correlation, and what implications can be drawn for the degree of capital mobility.

Overall, our results strongly supported the random coefficients approach, and while there are differences across groups in terms of the nature of the saving-investment relationship in the short run, we did find some support for the view that capital mobility is lower in countries with larger governments in the long run. This could mean that, the more interventionist the government, the greater the likelihood that domestic investment and long term economic growth will be tied to the domestic saving effort.

\section{REFERENCES}

1. AmirKhalkhali, S. and Dar, A., (1993). Testing for Capital Mobility: A Random Coefficients Approach, Empirical Economics, 18, 523-541.

2. Dooley, M., Frankel J., and Mathieson, D., (1987). International Capital Mobility: What Do Saving-Investment Correlations Tell Us? IMF Staff Papers, September, 503-530.

3. Feldstein, M. and Bacchetta, P., (1991). National Saving and International Investment. In: Bernheim, B.D. and Shoven, J.B. (Eds.), National Saving and Economic Performance, Chicago: University of Chicago Press, 201226.

4. Feldstein, M. and Horioka, C., (1980). Domestic Saving and International Capital Flows, Economic Journal, February, 314-329.

5. $\quad$ Feldstein, M., (1994). Tax Policy and Capital Flows, Weltwirtschaftliches Archiv, 130, 129-151.

6. Harberger A, (1980). Vignettes on the World Capital Market. American Economic Review, 70: 331-37.

7. IMF, (2002, 2006), International Financial Statistics Yearbook, Washington, D.C.

8. Jansen, W., (1996). Estimating Saving-Investment Correlations: Evidence for OECD Countries Based on An Error Correction Model, Journal of International Money and Finance, 15, 749-781.

9. Jansen, W., (1998). Interpreting Saving-Investment Correlations, Open Economies Review, 9, 205-218.

10. Murphy, R.G., (1984).Capital Mobility and the Relationship between Saving and Investment Rates in OECD Countries, Journal of International Money and Finance, 327-342.

11. OECD $(1999,2006)$. Economic Outlook, Organization for Economic Cooperation and Development. Paris, France.

12. Pratt, J. W. and Schlaifer, R., (1984). On the Nature and Discovery of Structure, Journal of the American Statistical Association, March, 9-33.

13. Pratt, J. W. and Schlaifer, R., (1988). On the Interpretation and Observation of Laws, Journal of Econometrics, September, 23-52.

14. Sachs, J., (1981). The Current Account and Macroeconomic Adjustment in the 1970s, Brookings Papers on Economic Activity, 1, 201-268.

15. Sachs, J., (1983). Aspects of the Current Account Behaviour of OECD Economies. In: Claasen, E. and Salin, P. (Eds.) Recent Issues in the Theory of Exchange Rates. Amsterdam and New York: North-Holland.

16. Summers, L. H., (1988). Tax Policy and International Competitiveness. In: Frankel, J. (Ed.) International Aspects of Fiscal Policies. Chicago: University of Chicago Press, 349-386.

17. Swamy, P.A.V.B., (1970). Efficient Inference in a Random Coefficients Regression Model, Econometrica, March, 311-323.

18. Swamy, P.A.V.B. and Mehta, J.S., (1975). Bayesian and Non-Bayesian Analysis of Switching Regressions and of Random Coefficient Regression Models, Journal of the American Statistical Association, September, 593-602.

19. Swamy, P.A.V.B. and Tavlas, G.S., (1995). Random Coefficient Models: Theory and Applications, Journal of Economic Surveys, 165-196.

20. Swamy, P.A.V.B., and Tavlas, G.S., (2002). Random Coefficient Models. In: Baltagi, B.H. (Ed.) Companion to Theoretical Econometrics, Basil Blackwell, 410-428. 